\title{
Early clinical outcomes of the surgical treatment of patients with aortic stenosis and small aortic annuli
}

\author{
Grzegorz Filip ${ }^{1}$, Krzysztof Bartuś ${ }^{1}$, Radosław Litwinowicz ${ }^{1}$, Janusz Konstanty-Kalandyk ${ }^{1}$, Maciej Bochenek ${ }^{1}$, \\ Piotr Węgrzyn ${ }^{1}$, Bogusław Kapelak ${ }^{1}$, Karol Wierzbicki ${ }^{1}$, Magdalena Bartuś², Jerzy Sadowski ${ }^{1}$ \\ ${ }^{1}$ Klinika Chirurgii Serca, Naczyń i Transplantologii, Collegium Medicum Uniwersytetu Jagiellońskiego, \\ Krakowski Szpital Specjalistyczny im. Jana Pawła II \\ 2Zakład Farmakologii Doświadczalnej, Katedra Farmakologii, Collegium Medicum Uniwersytetu Jagiellońskiego
}

Kardiochirurgia i Torakochirurgia Polska 2013; 10 (3): 199-203

\begin{abstract}
Background: Aortic stenosis is the most common acquired valvular heart disease. In some patients with small aortic annuli, after the surgical implantation of the artificial aortic valve, patient-prosthesis mismatch (PPM) may be observed. It can lead to an increased transvalvular gradient and decreased reduction of left ventricular hypertrophy. PPM is detected in patients with $\mathrm{iEOA}<0.85 \mathrm{~cm}^{2} / \mathrm{m}^{2}$.

The aim of the study was the evaluation of PPM incidence in relation to the size of the prosthetic valves implanted in patients undergoing aortic valve replacement, as well as the perioperative assessment of treatment results of PPM patients.

Material and methods: The study population included 92 patients, aged between 21 and 74 years old, who were implanted with St. Jude Medical mechanical aortic valves. The rate of complications and the echocardiographic parameters were evaluated. Patients were divided into three groups. The first study group consisted of 15 patients who underwent aortic valve implantation and received valves of small aortic annulus diameter (17 mm, $19 \mathrm{~mm})$, the second group included 56 patients who received medium-sized valves $(21 \mathrm{~mm}, 23 \mathrm{~mm})$, and the third one consisted of 21 patients who were implanted with valves of large aortic annulus diameter $(25 \mathrm{~mm}, 27 \mathrm{~mm}$, $29 \mathrm{~mm})$.

Results: In the first group, PPM was diagnosed in all patients, in the second group in $92.9 \%$, and in the third group in $52 \%$. Perioperative mortality was $5.4 \%$. Average transvalvular gradient in patients with small prostheses was $20.25 \mathrm{~mm} \mathrm{Hg}$, in patients with medium prostheses $13.42 \mathrm{~mm} \mathrm{Hg}$, and in patients with large prostheses $11 \mathrm{~mm} \mathrm{Hg}$.

Key words: aortic stenosis, PPM, surgical treatment.
\end{abstract}

\section{Streszczenie}

Wstęp: Zwężenie zastawki aortalnej to najczęstsza nabyta wada zastawkowa serca. U pacjentów z małym pierścieniem aortalnym, po operacji wymiany zastawki aortalnej na zastawkę sztuczną może wystąpić zjawisko tak zwanego niedopasowania rozmiaru zastawki do pacjenta (ang. patient-prosthesis mismatch - PPM), co może prowadzić do zwiększenia gradientu przezzastawkowego i mniejszej redukcji przerostu lewej komory. Zjawisko PPM jest rozpoznawane $u$ chorych $z$ indeksowaną efektywną powierzchnią ujścia (ang. indexed effective orifice area-iEOA) $<0,85 \mathrm{~cm}^{2} / \mathrm{m}^{2}$.

Celem pracy była ocena częstości występowania zjawiska PPM w zależności od rozmiaru implantowanej zastawki u pacjentów poddanych operacji wymiany zastawki aortalnej oraz okołooperacyjna ocena wyników leczenia.

Materiat i metody: Badana grupa obejmowała 92 pacjentów w wieku 21-74 lata, u których wszczepiono mechaniczne zastawki St. Jude Medical. Oceniano częstość powikłań oraz parametry echokardiograficzne. Chorych podzielono na trzy grupy. Pierwsza obejmowała 15 pacjentów, u których wszczepiono zastawki o małym pierścieniu (17 mm i $19 \mathrm{~mm}$ ), druga 56 chorych z zastawkami o średnim rozmiarze ( $21 \mathrm{~mm}$ i $23 \mathrm{~mm}$ ), a trzecia 21 pacjentów z zastawkami o dużym rozmiarze $(25 \mathrm{~mm}$, $27 \mathrm{~mm}$ i $29 \mathrm{~mm}$ ).

Wyniki: W pierwszej grupie PPM rozpoznano u wszystkich, w drugiej u 92,9\%, a w trzeciej u 52\% chorych. Śmiertelność okołooperacyjna wśród wszystkich osób poddanych operacji wyniosła 5,4\%. Gradient przez zastawkę aortalną u pacjentów z małą zastawką wyniósł średnio $20,25 \mathrm{~mm} \mathrm{Hg}$, u chorych ze średnią zastawką 13,42 mm Hg, a u pacjentów z dużą zastawką $11 \mathrm{~mm} \mathrm{Hg}$.

Słowa kluczowe: stenoza aortalna, PPM, leczenie operacyjne.

Address for correspondence: Grzegorz Filip, Klinika Chirurgii Serca, Naczyń i Transplantologii, Collegium Medicum Uniwerystetu Jagiellońskiego, Prądnicka 80, 31-202 Kraków, Polska, phone: +48 606457 247, e-mail: grzegorzfilip@onet.eu 


\section{Introduction}

Aortic valve stenosis is one of the most frequent diseases of the cardiovascular system encountered by surgeons during the course of their work. In recent years, the number of aortic valve implantation procedures has risen progressively in comparison to the decreasing number of coronary interventions.

In patients with small aortic annuli, after the aortic valve is replaced with a prosthetic valve, the phenomenon of patient-prosthesis mismatch (PPM) may occur. It may negatively affect hemodynamic parameters, result in transvalvular gradient increase, and prevent the reduction of left ventricular hypertrophy despite the normal functioning of the valve [1-3]. Consequently, this may lead to increased early and long-term mortality among the operated patients [4]. PPM is not a common problem, but, according to some studies, it may occur in as many as $70 \%$ of patients undergoing aortic valve replacement [5].

According to the original definition by Rahimtoola [6], PPM occurs when the effective prosthetic valve area, after insertion into the patient, is less than that of a normal human valve'. This stems from the fact that the implanted valve is placed intra-aortically and is equipped with its own annulus, which significantly reduces the diameter of the valve orifice area after implantation $[7,8]$. It is currently believed that the problem pertains to patients with indexed effective orifice area (iEOA) $<0.85 \mathrm{~cm}^{2} / \mathrm{m}^{2}[5,9]$.

Depending on the $\mathrm{IEOA}$ value, PPM is considered to be moderate for $0.65 \mathrm{~cm}^{2} / \mathrm{m}^{2}<\mathrm{iEOA} \leq 0.85 \mathrm{~cm}^{2} / \mathrm{m}^{2}$ and severe for $\mathrm{iEOA} \leq 0.65 \mathrm{~cm}^{2} / \mathrm{m}^{2}$. In different studies, iEOA $>0.85 \mathrm{~cm}^{2} / \mathrm{m}^{2}$ is considered either as mild PPM or insignificant PPM [10-12].

The data above indicate that surgeons can directly influence the improvement of the IEOA value by selecting appropriate prosthetic valves, which consequently leads to the improvement of hemodynamic parameters and helps avoid PPM [13-15].

Selecting prosthetic valves of appropriate sizes is particularly important in the case of patients with small aortic annuli, whose EOA is relatively small [12].

\section{Aim of the study}

The aim of the study was the evaluation of PPM incidence in relation to the size of the prosthetic valves implanted in patients undergoing aortic valve replacement, as well as the perioperative assessment of the treatment results of PPM patients.

\section{Material and methods}

The study encompassed 92 patients undergoing surgery, in whom mechanical St. Jude Medical valves of different sizes were implanted. The studied group consisted of 44 women (48\%) and 48 men (52\%), aged 21-74; mean age: 53.6 years ( \pm SD 9.8 years).

All patients were qualified for aortic valve replacement due to severe valvular stenosis of the left arterial orifice.
The patients were monitored perioperatively until their discharge from the hospital. The incidence of complications during the perioperative period was assessed, along with hemodynamic parameters after the implantation of prosthetic valves, by transthoracic echocardiography.

The patients were divided into 3 groups, based on the size of the implanted valves. The first group consisted of 15 patients who were implanted with valves of small aortic annulus diameter: $17 \mathrm{~mm}$ (3 patients) and $19 \mathrm{~mm}$ (12 patients). The second, largest group comprised 56 patients who were implanted with valves of medium aortic annulus diameter: $21 \mathrm{~mm}$ (29 patients) and $23 \mathrm{~mm}$ (27 patients). The third group consisted of 21 patients, who were implanted with valves of large aortic annulus diameter: $25 \mathrm{~mm}$ (16 patients), $27 \mathrm{~mm}$ (2 patients), and $29 \mathrm{~mm}$ (3 patients).

\section{Results}

Clinically significant PPM was revealed in all patients with small aortic annuli. Severe PPM was revealed in $87 \%$ of patients, moderate in $13 \%$ (iEOA ranged from $0.38 \mathrm{~cm}^{2} / \mathrm{m}^{2}$ to $0.8 \mathrm{~cm}^{2} / \mathrm{m}^{2}$; mean: $0.53 \mathrm{~cm}^{2} / \mathrm{m}^{2}, \pm S D 0.12 \mathrm{~cm}^{2} / \mathrm{m}^{2}$ ). The range of EOA was from $0.65 \mathrm{~cm}^{2}$ to $1.13 \mathrm{~cm}^{2}$ (mean: $0.88 \mathrm{~cm}^{2} \pm S D 0.13 \mathrm{~cm}^{2}$ ). The body surface area ranged from $1.42 \mathrm{~m}^{2}$ to $2.05 \mathrm{~m}^{2}$ (mean: $1.70 \mathrm{~m}^{2} \pm \mathrm{SD} 0.17 \mathrm{~m}^{2}$ ).

Among the patients with medium aortic annulus size, $48.2 \%$ suffered from severe PPM, $44.6 \%$ suffered from moderate PPM, and only $7.1 \%$ had no significant PPM (iEOA ranged from $0.4 \mathrm{~cm}^{2} / \mathrm{m}^{2}$ to $1 \mathrm{~cm}^{2} / \mathrm{m}^{2}$; mean: $0.68 \mathrm{~cm}^{2} / \mathrm{m}^{2} \pm S D$ $\left.0.12 \mathrm{~cm}^{2} / \mathrm{m}^{2}\right)$. The range of EOA was from $0.91 \mathrm{~cm}^{2}$ to $1.58 \mathrm{~cm}^{2}$ (mean: $1.23 \mathrm{~cm}^{2} \pm S D 0.16 \mathrm{~cm}^{2}$ ). The body surface area ranged from $1.51 \mathrm{~m}^{2}$ to $2.25 \mathrm{~m}^{2}$ (mean: $1.83 \mathrm{~m}^{2} \pm \mathrm{SD} 0.15 \mathrm{~m}^{2}$ ).

Among the patients with large aortic annulus size, 9.5\% suffered from severe PPM, $42.5 \%$ suffered from moderate PPM, and only $47.6 \%$ had no significant PPM (iEOA ranged from $0.61 \mathrm{~cm}^{2} / \mathrm{m}^{2}$ to $1.37 \mathrm{~cm}^{2} / \mathrm{m}^{2}$; mean: $0.88 \mathrm{~cm}^{2} / \mathrm{m}^{2}$ $\left.\pm S D 0.2 \mathrm{~cm}^{2} / \mathrm{m}^{2}\right)$. The range of EOA was from $1.35 \mathrm{~cm}^{2}$ to $2.43 \mathrm{~cm}^{2}$ (mean: $1.69 \mathrm{~cm}^{2} \pm S D 0.3 \mathrm{~cm}^{2}$ ). The body surface area ranged from $1.64 \mathrm{~m}^{2}$ to $2.20 \mathrm{~m}^{2}$ (mean: $1.94 \mathrm{~m}^{2} \pm S D$ $0.14 \mathrm{~m}^{2}$ ) (Fig. 1).

Perioperative mortality of all patients undergoing surgery amounted to $5.4 \%$. The largest percentage of perioperative deaths (20\%) concerned the group with small aortic annuli. It appears significant that all 3 persons who died in this group were diagnosed with severe PPM (iEOA $\leq 0.65 \mathrm{~cm}^{2} / \mathrm{m}^{2}$ ). In the group with medium valves, the perioperative mortality was $1.8 \%$ (1 patient with severe PPM).

Mean and peak transvalvular gradient, as well as the change in ejection fraction during the early postoperative period, were also assessed in relation to valve size.

The mean gradient through the aortic valve differed among the three groups during postoperative follow-up. The largest mean gradient was observed among the patients implanted with valves of small aortic annulus diameter; it was $20.25 \mathrm{~mm} \mathrm{Hg}( \pm S D=7.37)$. In turn, in the patients with medium aortic annuli, the mean gradient was $13.42 \mathrm{~mm} \mathrm{Hg}( \pm S D=5.94)$, and in the patients with large aortic annuli it was $11 \mathrm{~mm} \mathrm{Hg}( \pm S D=4)$. It appears impor- 


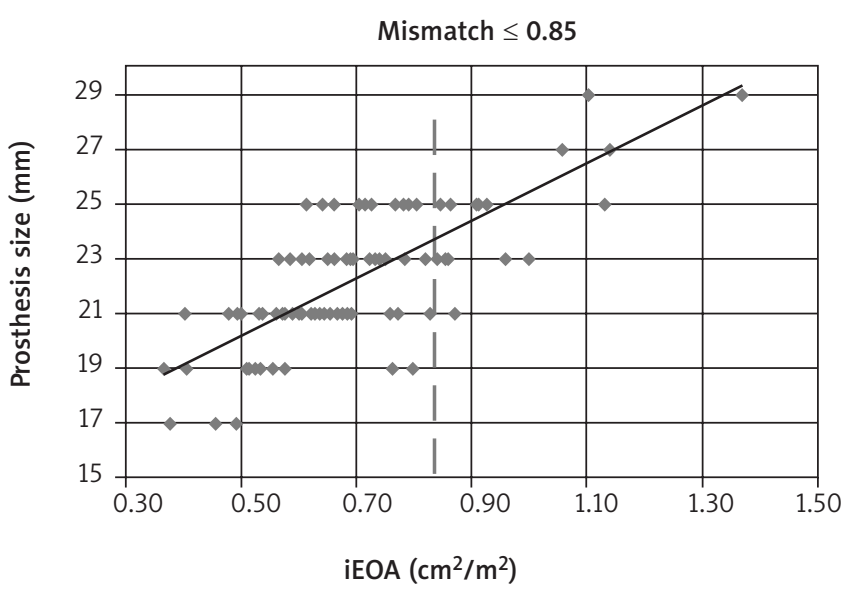

Fig. 1.

tant that the comparison between the mean gradient values of patients with small annuli and patients with medium ( $p=0.009)$ and large annuli $(p=0.001)$ indicated, in both cases, statistically significant differences, while the comparison between the gradient values of patients with medium and large annuli showed no such difference $(p>0.05)$. The peak transvalvular gradient among the patients with small, medium, and large valve annuli was, respectively: $34.75 \mathrm{~mm} \mathrm{Hg}( \pm \mathrm{SD}=11.34) ; 22.85 \mathrm{~mm} \mathrm{Hg}( \pm \mathrm{SD}=9.25)$; $18.18 \mathrm{~mm} \mathrm{Hg}( \pm \mathrm{SD}=6.35)$. In all three groups, statistically significant differences were found.

Changes in ejection fraction (EF) during the early postoperative period were noted in all three groups. In the group of patients with small aortic annuli, EF decreased in $67 \%$ of patients; the mean EF change within the whole group was $-7.58 \%( \pm S D=10.59)$. In the group of patients with medium aortic annuli, EF decreased in more than $80 \%$ of patients; the mean EF change within the whole group was $-10.68 \%$ $( \pm S D=11.22)$. Different results were noted in the group of patients with large aortic annuli, as the EF parameters in this group increased in $75 \%$ of patients, and the mean EF change was $+11.55 \%( \pm S D=11.97)$. These changes, however, are not statistically significant $(p<0.05)$.

The study also analyzed the characteristics of the implemented valve size distribution in dependence on gender, age, and BMI.

Valves with small aortic annuli were most often used in women (93\% women vs. $7 \%$ men), while valves with large aortic annuli were most frequently employed in men $(90.5 \%$ men vs. $9.5 \%$ women). Valves with medium annuli were used in the same number of men (50\%) and women (50\%). The distribution was statistically significant $(p<0.05)$ (Fig. 2).

No statistically significant changes were noted in any of the three groups with regard to patient age or BMI.

\section{Conclusions}

The occurrence of PPM among patients with small aortic annuli was relatively more frequent $(100 \%$ of iEOA results $\leq 0.85 \mathrm{~cm}^{2} / \mathrm{m}^{2}$ ) in comparison to other patients.

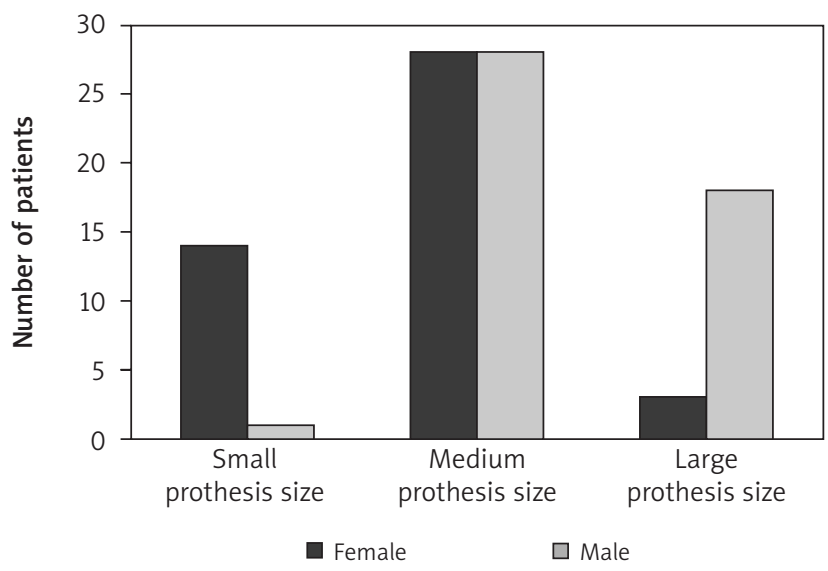

Fig. 2.

Female patients are particularly susceptible to the occurrence of severe PPM and high transvalvular gradient values.

The occurrence of PPM appears to be a factor increasing the risk of perioperative death in the studied group.

\section{Discussion}

Decreasing the transvalvular gradient is the primary objective of aortic valve replacement. Surgeons always prefer implanting the largest possible prosthetic valve if the aortic annulus is small, as it influences cardiac hemodynamic parameters and surgical treatment results. Nonetheless, the reduction of the gradient during the early postoperative period is often unsatisfactory due to the size of the employed valvular prosthesis $[13,17,18]$. Patient-prosthesis mismatch (PPM) is a frequently occurring problem which leads to the deterioration of hemodynamic function, results in a smaller postoperative reduction of left ventricular hypertrophy, increases the number of complications, and influences mortality.

Our study results provide evidence that the chance for PPM occurrence among patients with small aortic annuli (diameters $17 \mathrm{~mm}$ and $19 \mathrm{~mm}$ ) is higher (100\% of iEOA results $\leq 0.85 \mathrm{~cm}^{2} / \mathrm{m}^{2}$ ) than among patients in whom the diameter of the aortic annulus is more than $21 \mathrm{~mm}$. Women constitute a group that is particularly susceptible to the occurrence of severe PPM, which results from the fact that the body surface area and aortic annuli in women are significantly smaller in comparison to men [19]. These findings are supported by earlier publications from other centers [20].

According to some reports, the occurrence of PPM, in particular severe PPM, appears to be a factor which increases mortality during the early postoperative period [12]. In our study, almost all perioperative deaths occurred in patients with small aortic annuli, among whom $87 \%$ suffered from severe PPM.

The implantation of $17 \mathrm{~mm}$ and $19 \mathrm{~mm}$ valves was inextricably associated with significantly higher postoperative average and maximal transvalvular gradient values 
in the study group. Not only can this lead to enhancing the abovementioned risks related to PPM, but it can also result in faster degeneration of the implanted valve, provided that a biological valve was employed [19].

The development of cardiac surgery allows for a significant reduction of PPM, if not avoiding it altogether. This requires approaching each patient individually before the operation, calculating the desired EOA, and selecting appropriate valves for implantation.

The slight change in EF observed during the early postoperative period appears to be caused by the use of extracorporeal circulation during surgery. However, in-depth analysis of this phenomenon would require long-term EF observation, which was not the subject of this study.

The possibility of symptomatic PPM occurrence in patients with small aortic annuli may be significantly reduced, owing to the rich variety of valve prostheses and the availability of supra-annular prostheses providing better hemodynamic parameters.

Stentless valves may be used instead of mechanical prostheses and biological stent valves, as their different structure (no frame) allows for a larger orifice area, therefore providing better hemodynamic parameters [20-23]. Due to the larger iEOA of stentless valves, the risk of PPM occurrence is smaller than in the case of stent valves [24].

One of the more recent options is the use of sutureless valves [25]; their structure and hemodynamic properties allow for a significant improvement of the EOA size and hemodynamic parameters, particularly with regard to the transvalvular gradient.

Other methods of avoiding PPM include valve implantation with aortic annulus enlargement [22]. This procedure should be considered if iEOA $<0.65 \mathrm{~cm}^{2} / \mathrm{m}^{2}$. Its aim is the implantation of a larger prosthesis and achieving the assumed index [26]. Unfortunately, the database of the Society of Thoracic Surgeons indicates that performing this procedure is associated with a significant risk increase, which is why it is rarely performed [STS database].

Employing homografts and autografts (the Ross procedure) may also improve the hemodynamic parameters and reduce the possibility of PPM occurrence [27-30]. The use of these valves may, however, be constrained by their limited availability, technical difficulties, and greater complexity of the surgical procedure [23].

The results obtained in this study are supported by the conclusions of reports published by other centers. However, some reports indicate no PPM influence on perioperative mortality [24]. Therefore, the results concerning mortality should be interpreted with caution.

\section{References}

1. Dumesnil JG, Honos GN, Lemieux M, Beauchemin J. Validation and applications of indexed aortic prosthetic valve areas calculated by Doppler echocardiography. J Am Coll Cardiol 1990; 16: 637-643.

2. Pibarot P, Dumesnil JG, Lemieux M, Cartier P, Métras J, Durand LG. Impact of prosthesis-patient mismatch on hemodynamic and symptomatic status, morbidity, and mortality after aortic valve replacement with a bioprosthetic heart valve. J Heart Valve Dis 1998; 7: 211-218.
3. Yun KL, Jamieson WRE, Khonsari S, Burr LH, Munro Al, Sintek CF. Prosthesispatient mismatch: hemodynamic comparison of stented and stentless aortic valves. Semin Thorac Cardiovasc Surg 1999; 11 (Suppl I): 98-102.

4. Blais C, Dumesnil JG, Baillot R, Simard S, Doyle D, Pibarot P. Impact of valve prosthesis-patient mismatch on short-term mortality after aortic valve replacement. Circulation 2003; 108: 983-988.

5. Pibarot P, Dumesnil JG. Hemodynamic and clinical impact of prosthesispatient mismatch in the aortic valve position and its prevention. J Am Coll Cardiol 2000; 36: 1131-1141.

6. Rahimtoola SH. The problem of valve prosthesis-patient mismatch. Circulation 1978; 58: 20-24.

7. Perez de Arenaza D, Lees B, Flather M, Nugara F, Husebye T, Jasinski M, Cisowski M, Khan M, Henein M, Gaer J, Guvendik L, Bochenek A, Wos S, Lie M, Van Nooten G, Pennell D, Pepper J; ASSERT (Aortic Stentless versus Stented valve assessed by Echocardiography Randomized Trial) Investigators. Randomized comparison of stentless versus stented valves for aortic stenosis: effects on left ventricular mass. Circulation 2005; 112: 2696-2702.

8. Bartuś K, Sadowski J, Kapelak B, Myć J, Bartuś S, Oleś K, Filip G. Ocena efektywnej powierzchni ujścia i jej zmian w rocznej obserwacji u pacjentów z bezstentową, biologiczną zastawką 3F (ATS-Medtronic, Minneapolis) wykonaną z osierdzia końskiego. Kardiochir Torakochir Pol 2011; 8: 332-335.

9. Pibarot P, Dumesnil J. The relevance of prosthesis-patient mismatch after aortic valve replacement. Nat Clin Pract Cardiovasc Med 2008; 5: 764-765.

10. Howell NJ, Keogh BE, Barnet V, Bonser RS, Graham TR, Rooney SJ, Wilson IC, Pagano D. Patient-prosthesis mismatch does not affect survival following aortic valve replacement. Eur J Cardiothorac Surg 2006; 30: 10-14.

11. Pibarot P, Dumesnil JG, Jobin J, Lemieux M, Honos G, Durand LG. Usefulness of the indexed effective orifice area at rest in predicting an increase in gradient during maximum exercise in patients with a bioprosthesis in the aortic valve position. Am J Cardiol 1999; 83: 542-546.

12. Astudillo LM, Santana O, Urbandt PA, Benjo AM, Elkayam LU, Nascimento FO, Lamas GA, Lamelas J. Clinical predictors of prosthesis-patient mismatch after aortic valve replacement for aortic stenosis. Clinics (Sao Paulo) 2012; 67: 55-60.

13. Dumesnil JG, Yoganathan AP. Valve prosthesis hemodynamics and the problem of high transprosthetic pressure gradients. Eur J Cardiothorac Surg 1992; 6 Suppl 1: 34-37.

14. Pibarot P, Honos GN, Durand LG, Dumesnil JG. The effect of prosthesispatient mismatch on aortic bioprosthetic valve hemodynamic performance and patient clinical status. Can J Cardiol 1996; 12: 379-387.

15. Pibarot P, Dumesnil JG, Lemieux M, Cartier P, Métras J, Durand LG. Impact of prosthesis-patient mismatch on hemodynamic and symptomatic status, morbidity and mortality after aortic valve replacement with a bioprosthetic. J Heart Valve Dis 1998; 7: 211-218.

16. Martens S, Sadowski J, Friedrich S, Bartus K, Kapelak B, Sievers H, Schlensak C, Carrel T. Clinical experience with the ATS $3 f$ EnableR Sutureless Bioprosthesis. Eur J Cardiothorac Surg 2011; 40: 749-755.

17. Ihlen H, Mølstad P, Simonsen S, Vatne K, Ovrum E, Geiran O, Laake P, Frøysaker T. Hemodynamic evaluation of the CarboMedics prosthetic heart valve in the aortic position: comparison of noninvasive and invasive techniques. Am Heart J 1992; 123: 151-159.

18. Taggart DP. Prosthesis patient mismatch in aortic valve replacement: possible but pertinent? Eur Heart J 2006; 27: 644-646.

19. Breitenbach I, Wimmer-Greinecker G, Bockeria L, Sadowski J, Schmitz Ch, Kapelak B, Bartus K, Muratov R, Harringer W. Sutureless aortic valve replacement with the Trilogy Aortic Valve System: multicenter experience. J Thorac Cardiovasc Surg 2010; 140: 878-884.

20. Bartuś K, Sadowski J, Kapelak B, Myć J, Bartuś S, Oleś K, Konstanty-Kalandyk J, Wierzbicki K, Filip G. Prospektywna ocena zmiany wydolności krążenia u pacjentów z wszczepioną bezstentową, biologiczną zastawką aortalną wykonaną z osierdzia końskiego. Przegl Lek 2012; 69: 12-14.

21. Bartuś K, Sadowski J, Kapelak B, Myć J, Bartuś S, Oleś K, Konstanty-Kalandyk J, Wierzbicki K, Filip G. Ocena powikłań po wszczepieniu bezstentowej, biologicznej zastawki aortalnej wykonanej z osierdzia końskiego. Przegl Lek 2012; 69: 15-17.

22. Bartuś K, Sadowski J, Kapelak B, Myć J, Bartuś S, Oleś K, Filip G. Ocena gradientu przezzastawkowego bezstentowej, biologicznej zastawki 3F wykonanej z osierdzia końskiego - obserwacja roczna. Kardiochir Torakochir Pol 2011; 8: 328-331.

23. Wspólna Grupa Robocza Europejskiego Towarzystwa Kardiologicznego (ESC) do spraw Postępowania w Zastawkowych Wadach Serca i Europejskiego Towarzystwa Kardiochirurgów i Torakochirurgów (EACTS). Wytyczne 
dotyczące postępowania w zastawkowych wadach serca na 2012 rok. Kardiol Pol 2012; 70 supl. VII: 319-372.

24. Pepper J, Cheng D, Stanbridge R, Ferdinand F, Jamieson W, Stelzer P, Berg G, Sani G, Martin J. Stentless Versus Stented Bioprosthetic Aortic Valves: A Consensus Statement of the International Society of Minimally Invasive Cardiothoracic Surgery (ISMICS) 2008. Innovations (Phila) 2009; 4: 49-60.

25. Sadowski J, Kapelak B, Pfitzner R, Bartuś K. Sutureless aortic valve bioprothesis 3F/ATS Enable 4.5 years of a single-centre experience. Kardiol Pol 2009; 67: 956-963.

26. Pibarot P, Dumesnil JG. Prosthetic heart valves: selection of the optimal prosthesis and long-term management. Circulation 2009; 119: 1034-1048.

27. Sadowski J, Kapelak B, Bartuś K, Myć J, Drwiła R. Stentless 3F Therapeutics Aortic BioprosthesisTM - a new alternative to aortic valve replacement. Acta Cardiol 2004; 59: 231-232
28. Mohty D, Dumesnil JG, Echahidi N, Mathieu P, Dagenais F, Voisine P, Pibarot P. Impact of prosthesis-patient mismatch on long-term survival after aortic valve replacement: influence of age, obesity, and left ventricular dysfunction. J Am Coll Cardiol 2009; 53: 39-47.

29. Sadowski J, Kapelak B, Bartus K, Podolec P, Rudzinski P, Myrdko T, Wierzbicki K, Dziatkowiak A. Reoperation after fresh homograft replacement 23 years' experience with 655 patients. Eur J Cardiothorac Surg 2003; 23: 996-1001.

30. Stoliński J, Marek G, Marcinkowska Z, Jaskier M, Barecka D, Bartuś K, Kapelak B, Sadowski J, Dziatkowiak A. Allogenic heart valve bank in the Department of Cardiovascular Surgery and Transplantology of Jagiellonian University in Cracow - 23 years experience in the treatment of aortic valve or aortic root diseases. Cell Tissue Bank 2006; 7: 175-182. 